\title{
THE PROVISO TO SECTION 340(3) OF THE NATIONAL LAND CODE 1965 (NLC) : A STUDY
}

\author{
NORAIDA HARUN”, ASIAH BIDIN, NOOR 'ASHIKIN HAMID, KAMALIAH SALLEH \\ Faculty of Law and International Relations, Universiti Sultan Zainal Abidin, 21300 Terengganu, Malaysia, \\ noraida@unisza.edu.my* (Noraida Harun) \\ asiah@unisza.edu.my (Asiah Bidin) \\ shikin@unisza.edu.my (Noor 'Ashikin Hamid) \\ kamaliahsalleh@unisza.edu.my, (Kamaliah Salleh)
}

\begin{abstract}
Under the Torrens system, section 340 (1) of the NLC only gives the indefeasibility upon the registered proprietor. Fraud, misrepresentation, forgery, insufficient or void instrument and unlawful acquisition are the exceptions to the indefeasibility provided in section 340(2) of NLC. Under section 340(3)(a) or (b) of NLC, the person whose title is defeasible, if he had made a subsequent dealing on the land, the new proprietor's title still defeasible. The new proprietor will only get the protection under the proviso to section 340(3) of NLC if he can prove that he is a good faith purchaser. The proviso to section 340(3) applies only to the subsequent transferee and not the first transferee. The purpose of this article is to identify the criterions used by the courts in categorizing that person as bona fide purchaser, the position and the remedy of the bona fide purchaser in land matters. The methodology used in this study is a library based research which includes document analysis, such as the decided cases, book and articles. This study also discusses some suggestions for improvement and outcome to ensure the interests and rights of the parties involved.
\end{abstract}

Keywords: the proviso to section 340(3), criteria, position and remedies of the bona fide purchaser, suggestions. Article Received: 18 October 2020, Revised: 3 November 2020, Accepted: 24 December 2020

\section{Introduction}

Indefeasible concept of title to land applied when the proprietor registered his title according to the provision of the NLC. Sharifah Zubaidah (2008) stated in her article that indefeasibility can be obtained once registered and it cannot be challenged in any court unless it is coming under the circumstances laid down by section 340(2) of the NLC 1965.

In Khong Yoke Bee V. Lim Chong Yean \& another Appeal [2018] 3 CLJ 89, it was stated that the second defendant, as a registered owner had obtained the protection of title under section 340 of the NLC. The title could only be challenged and defeated by any of the stated grounds in section 340(2) of the NLC.

Thus, section 340 of NLC does not qualify a person who has in fact no title or interest to become a seller capable of divesting the registered owner of his interest in the title or interest and is not competent to create an instrument of transfer to pass title or interest. Grace (2011) stipulated that only the registered proprietor of that land entitled to have indefeasibility of title under the Torrens system.

\section{Methods}

The methodology used in this study is a library based research which includes document analysis, such as the decided cases, book and articles.

\section{Discussion}

\section{Concept of Deferred Indefeasibility Under} Section 340(3) of the NLC

Section 340(3) of NLC provides a proviso stating that "nothing in this sub-section shall affect any title or interest acquired by any purchaser in good faith and for valuable consideration, or by any person or body claiming through or under such a purchaser." This proviso clearly indicates that deferred indefeasibility is the applicable rule. In other words, the proviso to section 340(3) gives protection on a subsequent transferee and his title or interest will be indefeasible if he acts in good faith. 
In Au Meng Nam \& Anor v Ung Yak Chew \& Ors [2007] 5 MLJ 136, two fraudsters anticipated into an agreement to sell the plaintiff's property to the first defendant by forging the plaintiff's signature in the Form 14A. The plaintiff denied agreeing to the transfer of his property. The first defendant as a purchaser in good faith claimed that the second and third defendants were negligent when acted as solicitors for the first defendant in the sale agreement. The second and third defendants denied the liability and added the Johor Land Authority as a fourth defendant. The trial judge decided that the first defendant was a good faith purchaser, and applying the wrong explanation of section 340 of NLC in Adorna Properties Sdn Bhd v Boonsom Boonyanit [2001] 1 MLJ 241, where Adorna was entitled to indefeasible title. The Court of Appeal in Putrajaya reversed the trial court's judgment. Raus Shariff JCA and Hasan Lah JCA expressed the opinion that the Federal Court have to re-look at its judgment in Adorna Properties's case. Since the first defendant was an immediate purchaser, proviso to section 340(3) did not apply to him. In this case, the first defendant had not investigated all relevant matters pertaining the said sale and he could not be considered as a bona fide purchaser in good faith.

In Tan Ying Hong v Tan Sian San \& Ors [2010] 2 MLJ 1, the Court of Appeal held that the two charges in this case was obtained by void instruments and the charges were liable to be set aside at the request of the appellant, the registered proprietor. As the third respondent was an immediate holder of these charges, he could not obtain any protection provided under the proviso to section $340(3)$ of the NLC. Similar principle decided by the Federal Court in the case of Letchumanan Chettiar Alagappan @ LAllagappan (as executor to SL Alameloo Achi Alias Sona Lena Alamelo Acho, deceased) \& Anor v Secure Plantation Sdn Bhd [2017] 4 MLJ 697, where the immediate purchaser was not entitled to rely on the proviso in section 340 of the NLC.

In Sia Hiong Tee \& Ors v Chong Su Kong \& Ors [2015] 4 MLJ 188, the Federal Court held that proviso to section 340(3) of the NLC only gives security of title to a subsequent transferee. The concept of deferred indefeasibility applies according to this proviso.

According to the above discussion, the proviso to section 340(3) of the NLC is a statutory protection given to a subsequent purchaser when he is considered as a bona fide purchaser in good faith and his title becomes indefeasible under the NLC.

\section{Who is a Purchaser in Good Faith?}

The law in referring to bona fide has used the word purchaser in good faith. Thus, the principles of good faith operate to guarantee that both parties recognise the benefits of the agreement that entered into between the parties.

Among the criteria is, one must be a bona fide purchaser and for valuable consideration.

In the case of Ong Ban Chai v Seah Siang Mong [1998] 3 CLJ 670, defines 'bona fide': “...The meaning of the expression 'bona fide' may be found in legal dictionaries, e.g., Stroud's Judicial Dictionary and Words and Phrases and also in numerous judicial decisions. We found that the common factor in all bona fide transactions is the absence of fraud, deceit or dishonesty. In other words, they are entered into in 'good faith' for valuable consideration. The expression 'good faith' in English is used synonymously with the Latin expression "bona fide."

In State Tailor Sdn Bhd v Nallapan [2005] 2 MLJ 589 at 605 , the term bona fide purchaser means: "a buyer in good faith and the basic element of good faith is the absence of fraud, deceit or dishonesty and the knowledge or means of knowledge of such at the time of entry into a transaction". According to Nor Asiah (2004), the common characteristics of a bona fide purchaser include, "absence of fraud, absence of deceit or dishonesty, absence of undue influence and a contract which was entered in good faith for valuable consideration".

Another relevant criteria is, whether he is a purchaser who has paid the full purchase price.

In Aik Ming (M) Sdn Bhd \& Ors v Chang Ching Chuen \& Ors and Another Appeal [1995] 2 MLJ 
265, Gopal Sri Ram JCA said that: " the purchaser is considered as a bona fide until he paid all money under the contract for sale. A purchaser who pays only a deposit and, under the terms of a written or oral contract agrees to pay the balance later ( in the present case after three months), is not considered as a bona fide purchaser".

David Wong (1975) in his book stipulated that the word bona fide in section 340(3) of NLC should mean a genuine purchaser for value for the purchase of the land or interest. But in the case of $M \& J$ Frozen Food Sdn Bhd \& Anor v Sinland Sdn Bhd \& Anor [1994] 1 MLJ 294, states the element to qualify as a good faith purchaser is a purchaser who has paid full the purchase price. But in the case of auction sale, he must show that he is a purchaser who has paid within the time frame given by the law.

Next criteria is that a bona fide purchaser does not include a careless or negligent purchaser.

In Yap Ham Seow v Fatimawati bt Ismail \& Ors and Another Appeal [2014] 1 MLJ 645 and in the case of Au Meng Nam \& Anor v Ung Yak Chew \& Ors [2007] 5 MLJ 136, in both cases, the judges decided that a purchaser who is careless or negligent and concluded the sale without any appropriate investigation does not consider as a good faith purchaser.

Liputan Simfoni Sdn Bhd v Pembangunan Orkid Desa Sdn Bhd [2018] 3 MLJ 386, the Court of Appeal submitted that the question a court should ask when considering the issue whether a purchaser classified under the proviso to section 340(3) of the NLC had acted in 'good faith' or 'bona fides' was whether the purchaser had dealt honestly when he acquired title or an interest in the land. The issue of 'bona fides' had to be determined according to the facts in each case. Similar decision also stated in the case of T Sivam Tharamalingam v Public Bank Bhd [2018] 6 CLJ 1, the elements of good faith depends upon the circumstances of the case. Merely absence of fraud, dishonestly, knowledge of a dispute regarding to the ownership of property and knowledge of fraud allegation are not enough to fulfill the criteria of good faith.
Noraida \& Jady (2015) stated in their article that the concept of bona fide purchaser is not only depends on the payment of full purchase price, but other criteria have to be considered especially the element of good faith and not a negligent and careless purchaser.

The element of good faith requires the bona fide purchaser to act honestly and reasonably when deal with any transactions. He must also establish that in order to obtain ownership of any title to land, there was a genuine dealing and not considered as a careless or negligent purchaser. The responsibility to investigate all matters pertaining to the sale and purchase of the land is on the purchaser in good faith. When he fails to take any precautions, he is not permitted to obtain any protection according to the proviso to section 340(3) of the NLC.

\section{Suggestions}

According to Malaysian Torrens system practices, compensation funds never created because the system only operates by using two principles of mirror and curtain in the absence of the insurance principle. Therefore, the NLC as a source of reference for the land matters in Malaysia does not provide any provision of this compensation fund as a provision for protecting the land owner. (Siti Radiaton, Khadijah, 2012,Noraida, et al,2015, Salleh, et al,2017).

David S.Y. Wong (1977) commented that it is a defect system when the land registration system in Malaysia not provide any compensation scheme to a defaulted party. Andrew (2010) in his article stated that majority of countries that practice the Torrens system of land registration, an assurance fund is set up to compensate those whose interests are defeated, through no fault of their own and usually the money in then fund are contributed from registration fees paid on the lodgement of instruments of dealings for registration. He also suggested that it is time for us to look seriously into establishing an assurance fund in order to pay compensation to the innocent owner and the innocent purchaser. 
Kamilah \& Sharifah Zubaidah (2016) in their research stipulated the importance to have a statutory compensation scheme because our land law system in Malaysia was not sufficient to safeguard the rights and interest of the aggrieved party in land dealing. Meanwhile, according to Mohamad Shukri, Yusri \& Anesh (2013) in their article suggested that the procedures and regulations for processing of the claims in the Assurance fund are to be regulated under the State Land Rules and funding for the assurance fund is made through a specified percentage from all fees charged on all dealings under the NLC which is provided under the State Land Rule and a percentage of levies on land value which was affected the dealing under NLC.

Therefore, it is a necessary to have the insurance principle and a compensation scheme in order to overcome the future challenges in land dealing in Malaysia.

\section{Conclusion}

In Rajamani Meyappa Chettiar $v$ Eng Beng Development Sdn Bhd \& Ors (Court of Appeal) [2016] 4 CLJ 510 at 513, Abdul Rahman Sebli JCA stated that in order to give effect to article 13(1) of the Federal Constitution, a conflict between an innocent landowner whose title was protected by section 340(1) of the NLC and an innocent good faith purchaser who claimed protection under section 340(3) of NLC, the justice must be given to the innocent landowner. The question now, when the land was given back to the real owner, what was the protection given to the bona fide purchaser, like in Tan Ying Hong's case. As from the discussion above, as we overlooked to have an insurance principle in our land dealing, so no alternative compensation was given to the aggrieved party. According to Norasiah Chua, Ramzyzan, Muhammad Izwan \& Abdullah (2017) in their research stated that the country like Canada, Australia and Singapore, they provided the source for fund partly from dealing's levies and fees, caveats and withdrawal of caveats lodged under the land statute and the government 's offer to help any shortages covered under the fund. So, whatever ideas we may wish to import from others country require careful evaluation and study, and if these new ideas can be implemented here, we should also consider the suitable modification should be done. Salleh (2006) also commented that there are several ways and approaches to tackle the issue, but the route which we take should be under the right direction in order to achieve a good results.

\section{REFERENCES}

[1] Andrew, W.F.H.(2010). Recent Federal Court's decision on section 340 of the National Land Code: Tan Ying Hong $v$ Tan Sian San \& Ors - Are landowners and banks secured?. Praxis Chronicle The Malaysian Bar. Retrieved March 1,2019, from http://www.malaysianbar.org.my

[2] David, S.Y.W.(1975). Tenure and land dealings in the Malay states. Singapore: Singapore University Press.

[3] Grace, X.(2011). Indefeasibility of title in Malaysia - the revivification of deferred indefeasibility under the Torrens system focus on fraudulently obtained and forged titles. The Law Review,138-156.

[4] Kamilah Wati,M.Sharifah Zubaidah,S.A.K. (2016). Overview of the compensation scheme under the Torrens system: An analysis for adoption in Peninsular Malaysia. Jurnal of Asian and African Social Science and Humanities, 2(3), 1-11.

[5] Mohd Shukri,I.Yusri,Z.\&Anesh.G.(2013). Land administration system in Malaysia: The Torrens assurance fund. Jurnal Pentadbiran Tanah, 3(1), 53-60.

[6] Nor Asiah,M. (2004). A bona fide purchaser for valuable consideration: A special creature under the Malaysian land law, Proceedings of the International Real Estate Research Symposium (IRERS) 2004 (pp.427-436). Kuala Lumpur: Malaysia. 
[7] Harun, N. (2015). Pembeli bona fide dalam penipuan tanah: Isu dan cabaran. UUM Journal of Legal Studies, 6, 100-117.

[8] Harun, N., Ismail Nawang, N., \& Hassim, J. Z. (2015). Land Scams Involving the Power of Attorney in Land Dealings in Malaysia. VOL. 23 (S) NOV. 2015, 97.

[9] Nuraisyah Chua,A., Ramzyzan,R.,Muhammad Izwan, I, Abdullah, N.C.,\& et.al.(2017). Land Registration of Titles at Stake: West and East Malaysia compared, Proceedings of the $3^{\text {rd }}$ ABRA International Conference on Quality of Life "Quality of Life 3" (AQol2017) (pp.197-203). Kuching: Malaysia.

[10] Salleh.B.(2006). Security of tenure under the Malaysian Torrens system: What next after Boonsom Boonyanit?. Proceeding of the International Real Estate Symposium (IRERS) (pp.231-236). Kuala Lumpur: Malaysia.

[11] Salleh, K., Harun, N., Bidin, A., \& Hamid, N. A. (2017). Land Administration: Issues and Way Forward. Pertanika Journal, Social Sciences \& Humanities, 25, 225230.

[12] Sharifah Zubaidah, S.A.K.(2008). Indefeasibility of title and interest. In Ainul Jaria, M. et. al.(Eds), Principles of Malaysian Land Law (pp.163-179). Kuala Lumpur: Lexis Nexis, Malayan Law Journal.

[13] Siti Radiaton Adawiyah, Z., Khadijah,H. (2012). Proceedings of the $3^{\text {rd }}$ International Conference on Business and Economic Research (3 ${ }^{\text {rd }}$ ICBER 2012), Bandung: Indonesia. pp. 1616-1620. Retrieved March 1 2019, from http://www.internationalconference.com.m $\mathrm{y}$ 